\title{
顔面神経減荷術後の感音難聴
}

\author{
鹿児島大学医学部耳鼻咽喉科学教室（主任：大山 勝教授) \\ 小川和昭, 渡辺荘郁, 岩淵康雄, 原口兼明 \\ 広田常治, 昇卓夫, 大山腾
}

\section{SENSORINEURAL HEARING LOSS FOLLOWING THE DECOMPRESSION OF THE FACIAL NERVE}

\author{
KAZUAKI OGAWA, M.D., SOIKU WATANABE, M.D., YASUO IWABUCHI, M.D. \\ KANEAKI HARAGUCHI, M.D., JOHJI HIROTA, M.D., TAKUO NOBORI, M.D. \\ and MASARU OHYAMA, M.D.
}

Department of Otolaryngology, Faculty of Medicine, Kagoshima University, Kagoshima

This study aims to ascertain whether sensorineural hearing loss occurs after the decompression of the facial nerve. Nine patients have undergone decompression of the facial nerve (limited to the vertical segment) by the transmastoid approach were selected as the subjects of this study because the influence of disinfectants and surgical trauma on the inner ear seems to be less severe in this operation than in tympanoplasty. Additionally, this approach seems to be more suitable for judgement of the effect of the drilling noise induced acoustic trauma on the inner ear than tympanoplasty.

Though high tone abrupt sensorineural hearing loss was occured in the operated ear in seven patients, no changes in hearing level were found in the contralateral side ear. Bekesy audiometry performed in only one case revealed Jerger II which suggested some disorder in the cochlea.

Not only acoustic trauma induced by the drilling noise but also labyrinthitis occurred via the opened facial canal and the internal ear canal seemed to be the cause of sensorineural hearing loss following the decompression of the facial nerve.

Key words : 顔面神経減荷術, 中耳手術, 術後感音難聴

1.はじめに

中耳や顔面神経麻㾝に対する手術操作が, 内耳障害 を発生させるとする多くの報告がある。このような手 術後感音難聴の発生原因として1）手術操作による炎 症の内耳波及，2）手術時に用いた消毒剤，3）局所麻 酔郕，4）バー，ノミによる外力，5）中耳腔に入れた 人工耳小骨等の異物反応又は压迫, 6) ガ一ゼによる压 迫，7）術後感染などがある. 今回著者らは, 上記原因 のうち特にバー，ノミの使用に上る内耳への影響を， 垂直部に限られた顔面神経減荷術を行った症例老対象 に検討した。

\section{2. 対象及び方法}

1985年 3 月より1989年10月まで, 当教室で行った経 乳突法により顔面神経の垂直部のみを開放した症例 9 例を対象とした，今回著者らは，真珠腫による内耳㾇 孔がなく, 真珠腫や炎症性肉芽の除去に伴う中耳操作 がなく，しかもバーやノミによる耳小骨接触の可能性 の低い垂直部に限局した顔面神経減荷術施行例を対象 に選ぶことで，バーやノミの使用時に発生する騒音が 果たして内耳障害を来し得るのかを検討することを企 図した. 疾患の内訳は表 1 に示すごとくぶル麻瘒 5 例, ラムゼー・ハント症候群 3 例, 外傷性顔面神経麻瘟 1 
例であった。症例 $1 \sim 7$ はバー, ノミの両方を, 症例 8 と 9 はバーのみを使用した，減荷部位は垂直部に限 られており，術中にバーの耳小骨接触の記載のないも のであった。また全症例鼓膜穿孔や中耳炎の合併はな く,消毒液が中耳腔に及んだ可能性はないものである。 聴力障害判定基準は以下のごとくである.

1） $15 \mathrm{~dB}$ 以上の闘值上昇をみたもの

2）スケールアウトに変化したもの

上記 1，2の少なくとも1つの条件を充たすものと した.

後述するごとく, 術側とは反対側耳（健側耳）の聴 力は術前術後で全周波数において骨導及び気導ともに 有意の変化はなく,かつその標準偏差值忏すべて

表 1 顏面神経隇荷術症例 (9)

\begin{tabular}{rrrlrccc}
\hline \multirow{2}{*}{ 症例 } & 年齢 & \multirow{2}{*}{ 性 } & 診断 & \multicolumn{3}{c}{ 聴力障害 } \\
\hline
\end{tabular}

$\mathrm{M}$ : 男性, F：女性

ベル：ベル麻㿁, ハント：ラムゼー・ハント症候群
10dB以内であった。したがって術後には，15dB以上 の変化を有意な变化とした。また $15 \mathrm{~dB}$ 以内の変化て あっても、スケールアウトをしめしたものはやはり有 意な変化とした。スケールアウトした場合，その值に $5 \mathrm{~dB}$ を足した值をその周波数における聴力レベルと して計算した。

最終施行聴力検查結果をその術後聴力としたが, 最 短は術後21日で最長は150日，平均25日であった。

\section{3. 結 果}

全症例の臨床成績を総括したのが表 1 である.

耳鳴り，めまいは，ともにカルテ記載の明確であっ た 6 例中 1 例のみに認められ，いずれも一過性で 1 週 間以内に消失した。

術側耳の聴力低下は 9 例中 7 例に認められ，いずれ も高音急檠型であったが, 術側と反対耳の聴力低下は 全例で認められなかった。術後アミノ配楉体抗生剂を 症例 4 のみに使用しているが，術側のみの聴力障害で 反対側は変動しなかった。

図 1 は, 反対側耳の術後聴力変化を示す. 術前の聴 力を $0 \mathrm{~dB}$ とした際の術後の聴力変化を, 平均値士標準 偏差值で示した，全周波数領域で骨導，気導ともに統 計学的に有意な聴力低下は示さず,最大標準偏差值は, $8000 \mathrm{~Hz}$ における気導の $8.4 \mathrm{~dB}$ であった。

図 2 は, 術側の気導聴力で, 術前術後の実測値を現 わしたものである。

図 3 は, 図 2 と同様に術側の気導恥力であるが, 術 前值を $0 \mathrm{~dB}$ とした際の術後聴力の変化を平均値士標 準偏差値で示す. 4000 及び $8000 \mathrm{~Hz}$ において，それぞ れ $5 \%$ おび $2 \%$ 以下の危険率で統計学的に有意な聴

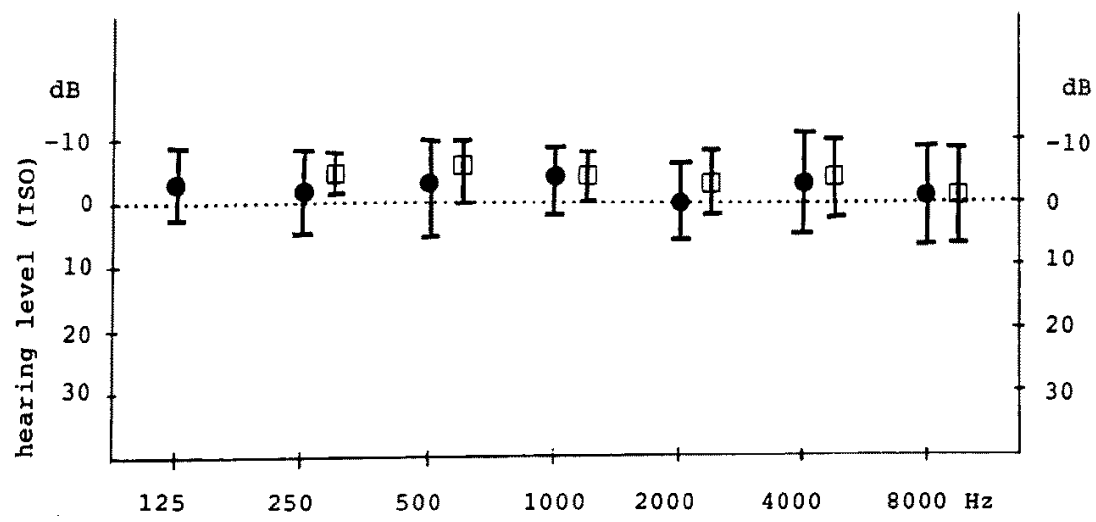

図 1 健側耳における術後聴力の変化. 術前聴力を $0 \mathrm{~dB}$ とした。

：気導， $\square$ : 骨導 


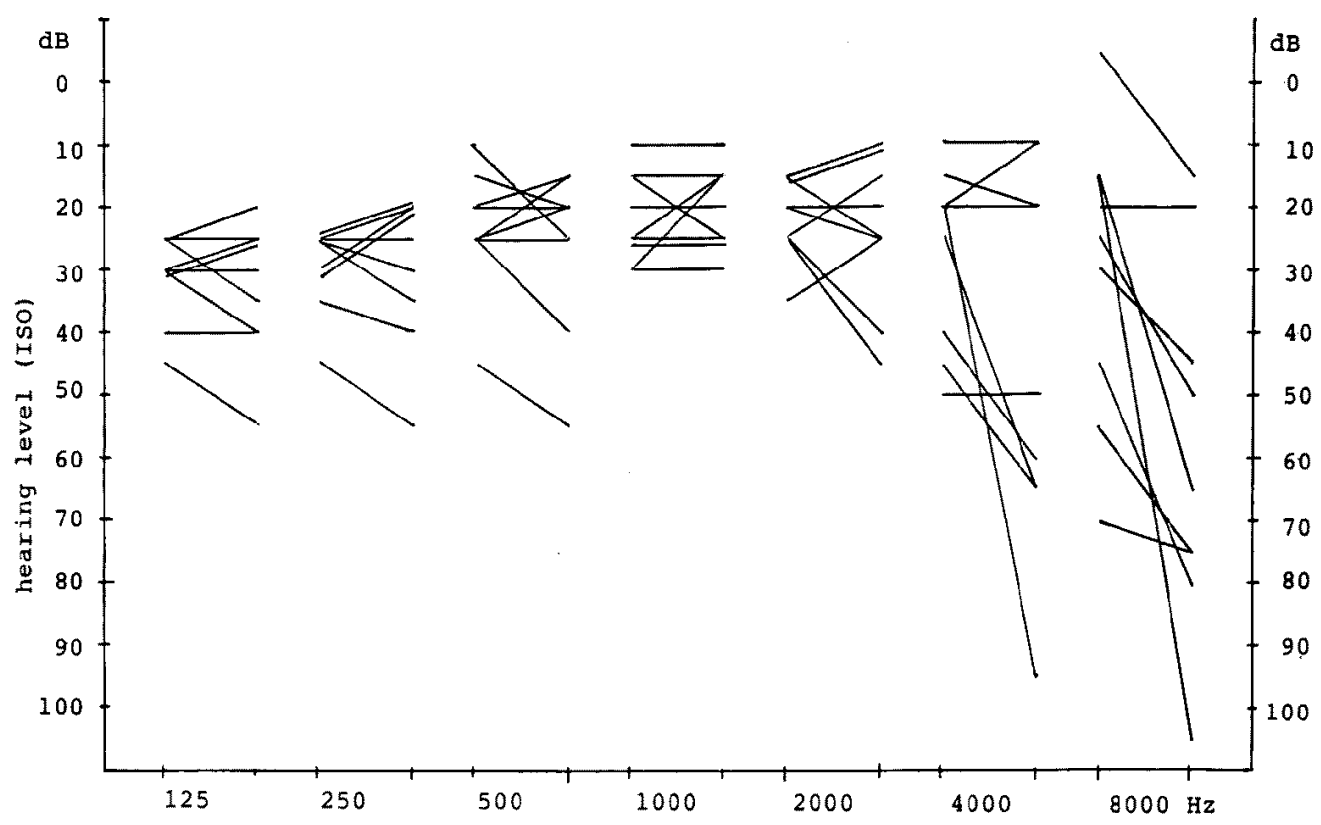

图 2 術側耳における術後気導聴力の変化

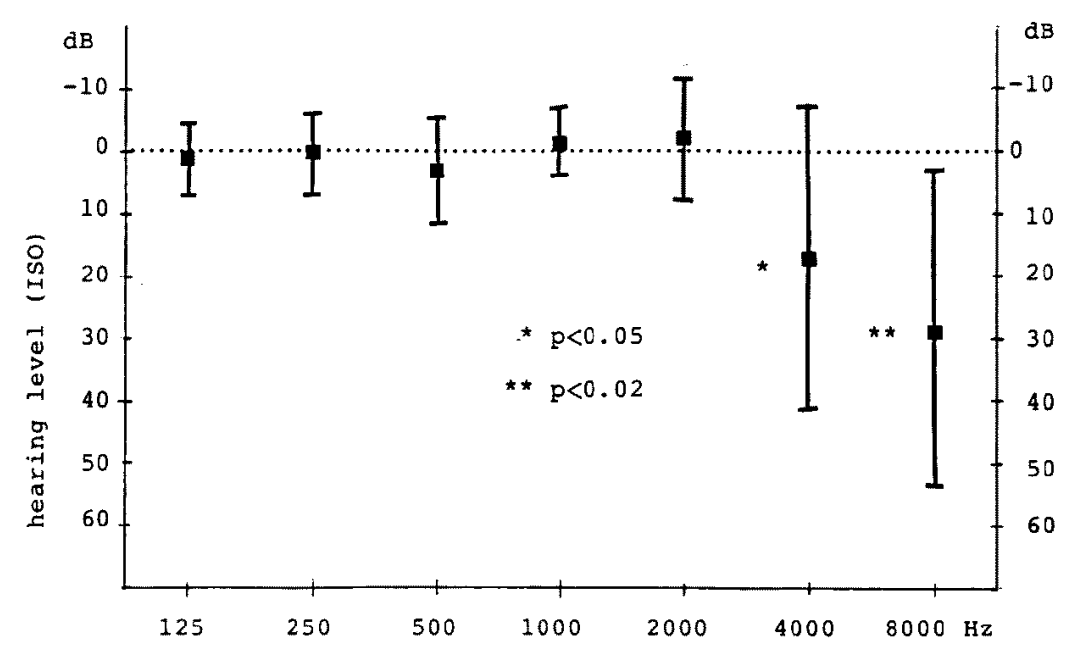

图 3 術側耳に扝ける術後気導聴力の变化. 術前聴力を $0 \mathrm{~dB}$ とした.

力低下がみられた。

図 4 は, 術側の骨導聴力で, 術前術後の実測值を示 したものである。

図 5 は, 図 4 と同様に術側の骨導聴力であるが, 術

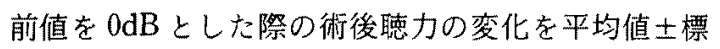
準偏差值で現わしている。 $8000 \mathrm{~Hz}$ に扔いて $5 \%$ \%下 の危険率で統計学的に有意な聴力低下が認められた。

\section{4. 症例}

㩆著な聴力障害を来した症例 3 の経過を紹介する. 症例は，41歳の女性で, 診断は左ラムゼー・ハント 症候群. 発症後高気圧酸素療法, 星状神経節ブロック, ステロイド剤の漸滅療法, ビタミン B 剂等による治療 を行ったが緩解の傾向がえられず，完全麻㾇に近い状 態であった。しかし，鐙骨筋反射が正常であったため 発症後 3 力月後に垂直部の顔面神経減荷術を施行し た。術翌日上り左（術側）向きの水平性自発眼振を伴 うめまいが出現したが，2-3日で次第に消失した。 


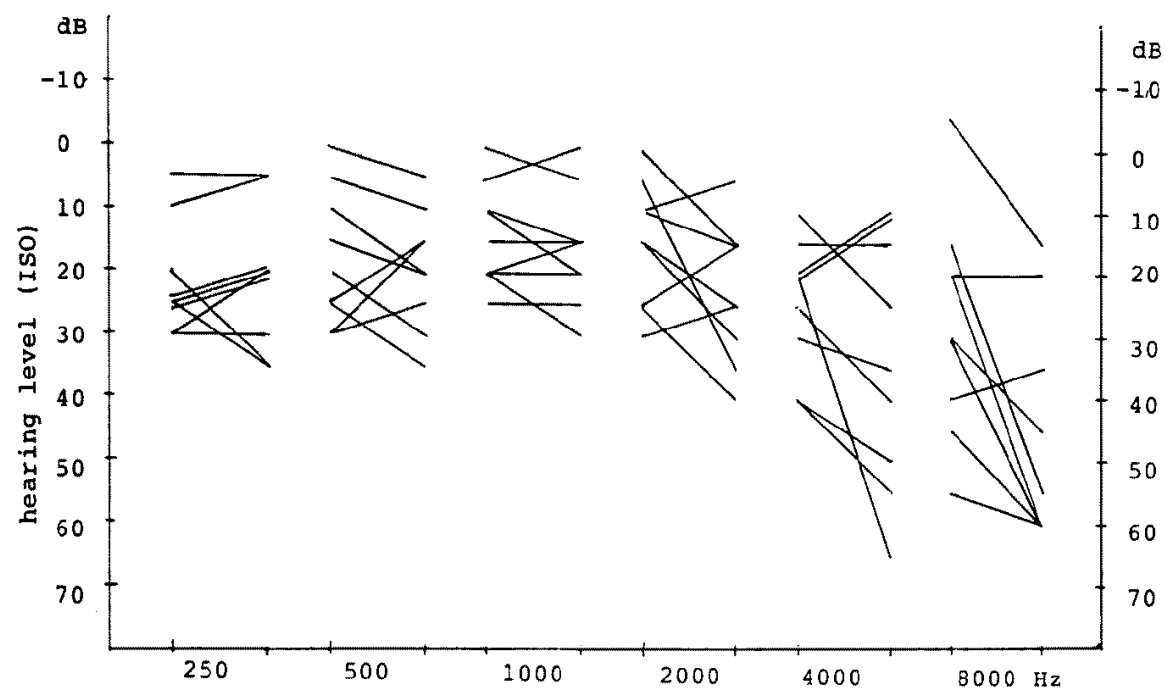

図 4 術側耳における術後骨導聴力の変化

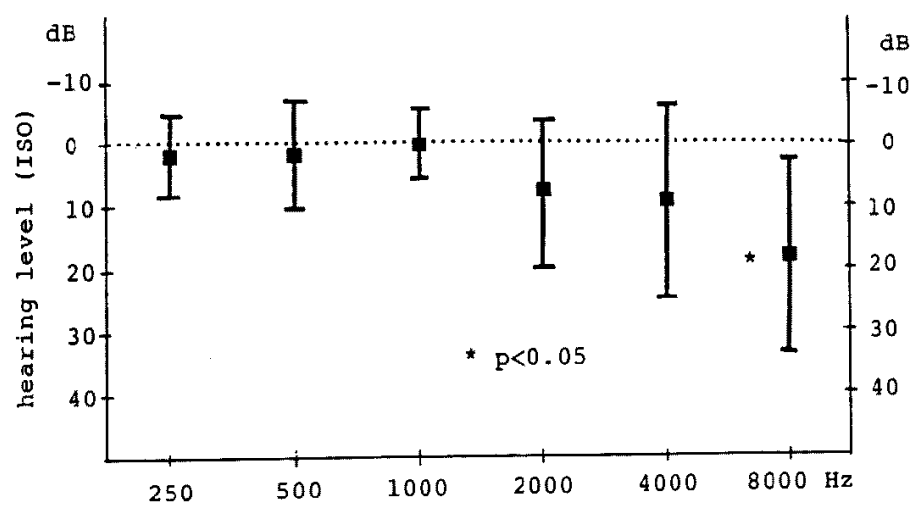

图 5 術側耳に扔ける術後骨導聴力の変化。術前聴力を $0 \mathrm{~dB}$ とした。

術後耳鳴りはなかったが, 術後12日目の純音聴力検査 では術側耳の高音急侀型感音難聴を来し，図 6 に示す ごとく術後150日経過した時点でもほとんど改善はみ られなかった。術後150日目に施行した自記オージオグ ラムは, 図 7 に示すごとく Jerger II 型で,内耳障害が 示唆された。

\section{5. 考察}

中耳手術後に感音難聴を来すことに関してはすでに

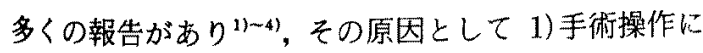
上る炎症の内耳波及(内耳瘦孔加らの炎症波及も含 め)，2）手術時に用いた消毒剂(クロルヘキシジン，ポ ピドンヨードなど）の影響，3）局所麻酔剤（リドカイ ン，プロカインなど）の作用，4）バー，ノミによる外
力，5）中耳腔に入れた人工耳小骨などの異物反応また は圧迫，6)ガーゼによる圧迫，7)術後感染などがあ

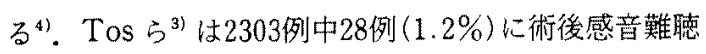
を認め,この内 12 耳 $(0.5 \%)$ は完全望で, 16 耳は 80 $100 \mathrm{~dB}$ の聴力障害を来し, いずれも高音急檠型であっ たと報告している。その原因として, 特に完全穓を来し た症例では過度の操作やバーに上る耳小骨への接触も その一因となり得るとした。またT.Palvaら”は1680 例を検討した結果，75例(4.5\%)に術後感音難聴を認 め,バーによる耳小骨への接触や, 耳小骨周辺の肉芽除 去時の過度の内耳への振動がその原因であるとした。

一方, 中耳手術の際のバーゃノミの使用時に発生す る骨導音による内耳障害も晒念され，バーゃノミ使用 時の術側及び対側の骨導音レベルに関するヒト側頭骨 


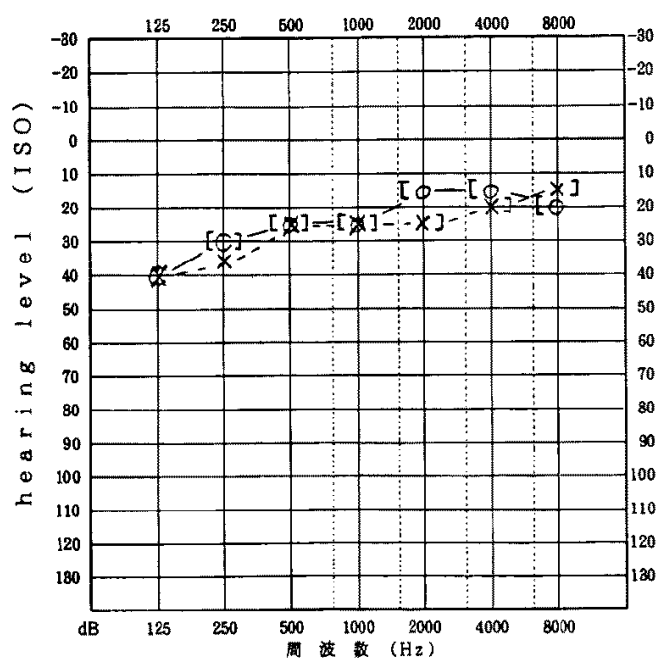

行前前

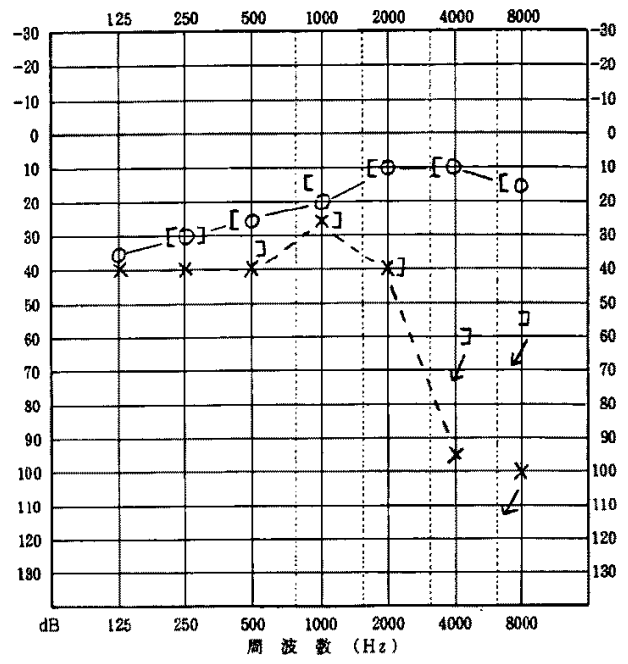

街挠150日目

図 6 オージオグラム

症例: 41歳, 女性, ラムゼー・ハント症候群

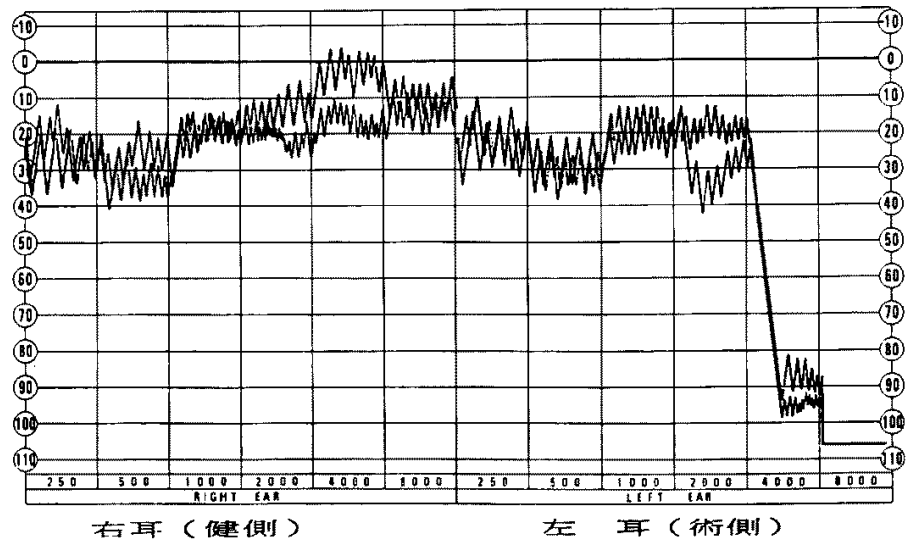

図 7 自記オージオグラム（術後150日目）

症例：41歳，女性，ラムゼー・ハント症候群

や死体を用いた詳細な実験も報告されている年)6)．を れらの報告によれば，乳様突起部削開時の術側耳には $100-110 \mathrm{~dB}$ の骨導音が伝達され，対側耳には5一 10dBの減衰を以て伝わる. Kylen ら レベルの骨導音が鼓室形成術後に生じる高音障害型の 感音難聴の原因と成り得るとしている。しかし， Parkin ら”は対側耳て聴力障害が発来しない理由と して 5-10dBの減衰だけでは説明できないとして，吸 引操作による騒音に着目した，彼らの実験結果による と, 吸引操作単独で発生する気導音は平均 $107 \mathrm{~dB}$ にも 及び，更にバーとの同時併用によりバー単独時より 10
-31dB 増幅される.したがって，そのことが術側耳の 感音難聴の発生原因であろうと推测している。一方瀧 本 ${ }^{4}$ 心，モルモットの中耳学胞に注入した生理食塩水 を $19 \mathrm{G}$ 静脈力テーテルで蛸牛空付近より吸引するこ とで, 吸引操作の内耳への影響をみる実驗を行ってい るが, 有毛細胞の変化は認められないとしている.以 上のごとく，バーやノミの使用時に発生する騒音によ つて果たして内耳障害が発来するのか, また内耳障害 が生ずると仮定すれば対側耳に聴力障害が生じないの は単に5-10dBの骨導隇衰のみによることで説明で きるものなのかなど，いまだその機序は十分解明され 
ていない。

今回著者らは，真珠腫による内耳㿔孔がなく，真珠 埂や炎症性肉芽の除去に伴う中耳操作がなく，しかも バーやノミによる耳小骨接触の可能性の低い垂直部に 限局した顔面神経減荷術施行例を対象に選ぶことで, バーやノミの使用時に発生する騒音が果たして内耳障 害を来し得るのかを検討することを企図した。その結 果, 9 例中 7 例に高音急裂型の聴力障害が認められ，し かも内耳障害による骨導低下がその原因と思われた。

内耳障害を来した原因として次の二つの機序が考え られる、第一は騒音による内耳障害である。しかしな ぜ 9 例中 7 例 $(77 \%)$ と極めて高率に発生したのか. これにはいくつかの要因が考えられる，そのひとつに

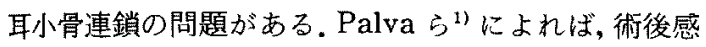
音難聴を来した75例中耳小骨連鎖が正常であった例が 61例 (81.3\%) と高率に占めている. Smyth ${ }^{2)} も$ 同様な 理由で，術中特に上鼓室の操作が必要な症例において は予め砧骨を除去することが, 術後感音難聴発生を予 防するうえで重要であるとしている，中耳炎の症例と 異なり, 今回の著者等の症例は全例耳小骨連鎖は正常 であったため内耳障害が特に高率に生じたことも否定 できない.しかし Palva らやSmythの意味するのは， 砧骨を除去することにより，バーの耳小骨接触や耳小 骨周囲の病的組織除去時に鐙骨を介した内耳への振動 を防げるということであり，著者らの症例には必ずし もあてはまらない、しかし著者らは，バーやノミ使用 時に発生する騒音による内耳障害の原因として，骨導 音以外に経鼓膜的に鐙骨を振動させる気導音が重要で あると考えて㧍り，その意味でやはり耳小骨連鎖状態 は重要な意味があると考える。その詳細な理由につい ては後述する．次にこのような術後感音難聴が高率に 発生した要因として，対象疾患の相違によるものが考 えられる。すすなわ占他の報告 ${ }^{12231}$ は慢性中耳炎を対象 疾患としており，今回著者らは顔面神経麻粨をその対 象としたことである. 後藤" は, 鼓室形成術後の内耳障 害を検討しているが，そのなかで術前骨導低下がすで に認められる症例の方が術後更に骨導低下を生じやす いとする結果を得ており, その理由として騒音に対し て内耳が障害される準備状態が形成されている可能性 を述べている，今回の著者らの対象としたベル麻痺ま たはラムゼー・ハント症候群例では镫骨筋麻瘦の既往 がありここれちも含めて骨振動や騷音に対する内耳 の易受傷性が高まっていることも十分想像される.

内耳障害を来した第二の原因としては内耳炎が挙げ

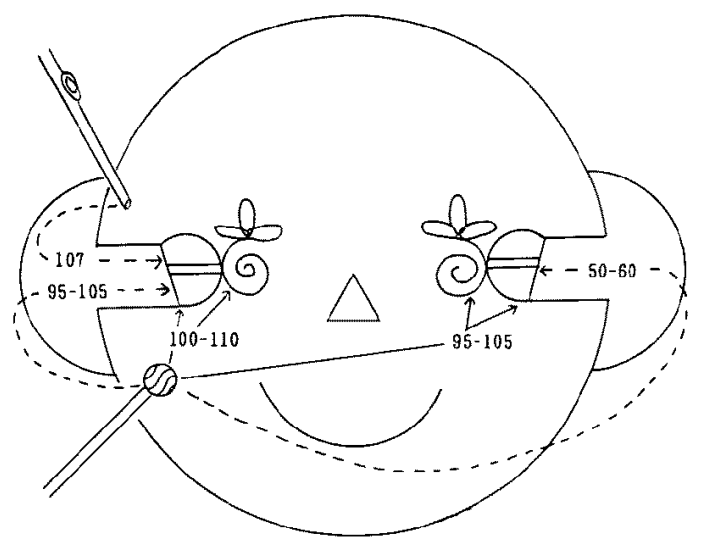

図 8 乳突洞削開術時におけるバーと吸引操 作によって発生する騒音 算膗音 $(\mathrm{dB})$ : 気湆音 $(d B)$ :

られる.内耳道底には前庭神経, 螖牛神経抢よび顔面 神経の通るための小子があり，兴脊髉液はこれらの小 孔を通って内耳及び側頭骨内の顔面神経管内に入り得 $3^{3)}$. したがって顔面神経減荷術時に神経䩗を切開し た場合，炎症は逆行性に内耳道に至り，更に内耳八と 波及し得尚。その結果，内耳掼孔の際に㷋症が内耳人 波及するのと同じ結果となる。本症例における耳鳥り やめまいも内耳炎に伴う症状であった可能性もあり， そのような症状のない症例でも臨床的には確認し得な い程度の軽い内耳炎を起こしているのかもしれない. なぜ対側耳に聴力障害は発来しないのが.このことは 結局，どのような機序で術側の内耳障害が生じるのか という命題と同じことである。少なくとも，対側耳に 内耳障害は生じないということでは意見は一致してい $ろ^{(1) \sim 4} し ， 今$ 回の著者らの結果もまったく同じである。 Kyley ら ${ }^{\text {5) } と \text { Parkin ら }}{ }^{6)}$ はその機序解明のため, 人側 䫒骨や死体を用いた詳細な基礎実験を行っているが, それらのデータをもとに作成したのが図 8 である. Kyley $ら^{5)}$ はバーによる骨導音そのものが, Parkin $ら^{\text {) }}$ は骨導音に加えて吸引操作によって発生する気筫 音の関与が内耳障害の原因として重要であり，したが って両耳間に扔ける骨導音の減衰 $(5-10 \mathrm{~dB})$ や吸引操 作による気導音の関与 $(107 \mathrm{~dB})$ の有無が対側耳で内耳 障害の発生しない理由であるとしている。それに加え て著者らはバーによって発生する気導音が重要な因子 であり，経鼓膜的に内耳のリンハ液を振動させること が有毛練胞の聴毛障害を惹起しやすいものと考える. 鼓室形成衍後の感音性難聴が耳小骨連鎖が正常である 
例に扔いて高率に発生するこど, 更に砧骨の除去が その予防に役立つこどなどにはの気導音の関与も その一因であると考える。従ってこの気導音が 95$105 \mathrm{~dB}$ と高レベルに達する術側では内耳障害が発生 し得るが，50一60dBにすぎない対側耳では発生しな いと思われる。

中耳手術後感音難聴の原因は必ずしも明確ではない

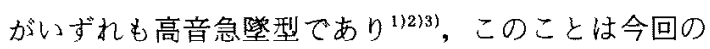
著者らの結果と一致する. Palvaらは loudness balance test, Bekesy audiometry による補充現象を確認 し，その結果螖牛障害が感音韄聴の責任病巣であると している.今回著者らは 1 症例にのみBekesy audiometry を施行し得たが, Jerger II 型でやはり蝸 牛障害が示晙された。一方, $20 \mathrm{kHz}$ 迄発生可能なオ一 ジオメーターを用いて乳椂突起削開術後”’，仕事場 で長期間騒音に暴露された症例 ${ }^{10)}$ を対象に高周波数 領域における可聴間值の変化をみている報告がある。 それらの報告によると $8 \mathrm{kHz}$ 以下の領域で臨床的な聴 力障害が発現する以前に，その閾值が低下する，すな わち聴きとれる可能な周波数上限值が低下してくる. なぜ騒音による蜳牛障害が基底回転から始まるのかは 必ずしも明確にされてはいないが，基底回転に扔ける 血管の脆弱性や血管条の未発達 ${ }^{11121}$ が指摘されてお り，そのため音響暴露時にいち早く代謝障宫が生じる ものと考えられている ${ }^{9)}$ ，バーやノミの使用は中耳の 手術の際必須であるだけに術者の内耳に対する注意深 い配慮が必須である. Cutting burr は diamond burr に比べ約 $5 \mathrm{~dB}$ 大きい騒音を発生し5), 更にバーの回転 数も影響を与える は予め砧骨を除去することが望ましく(1)2), 乳様突起削 開術の場合のその必要性も今後検討すべき課題だと思 われる. 今回著者らは全例に対し術後ステロイド剂, ビタミン B 郕, 末梢偱環改善剂を使用しているが，そ れらの効果は不確実であるとされておりり年, 今後内耳 障害を予防するような薬剤の開発が望まれる。

\section{6. ま と め}

顔面神経垂直部減荷術施行の聴力障害について検討 した。その結果次の成績が得られた。

1. 健側耳の聴力障害は認められなかった。

2. 術側耳の聴力障害は 9 例中 7 例に認められ，い ずれも高音急型であった。
3.パーやノミによる騒音(骨導音と気導音), もし くは内耳炎による蛸牛障害がその原因と思われた。

4. 術式の工夫と共に, 聴力障害を予防軽減するよ うな薬剤の開発が望まれる。

\section{参考文献}

1) Palva T, Karje J, Palva A : High-tone sensorineural losses following chronic ear surgery. Arch Otolar. yngol 98: 176-178, 1973.

2) Smyth GDL: Sensorineural hearing loss in chronic ear sugery. Ann Otol Rhinol Laryngol 86: 1-6, 1977.

3) Tos M, Lau T, Plate $S$; sensorineural hearing loss following chronic ear surgery. Ann Otol Rhinol Laryngol 93: 403-409, 1984.

4）瀧本 勲: 中耳手術一その操作と内耳への影響. 耳鼻 䠛床 78:465-476, 1985 .

5) Kylen P, Arlinger S: Drill-generated noise levels in ear surgery. Acta Otolaryngol 82: 402-409, 1976.

6) Parkin JL, GS Wood, RD Wood et al : Drill- and suction-generated noise in mastoid surgery. Arch Otolaryngol Head Neck Surg 106: 92-96, 1980.

7) 後藤修二：鼓室形成術による内耳障害. 耳侯 $43: 201$ -205. 1971.

8）吉本 裕：内耳道, 野村恭也 編: 臨床耳鼻咽俟科頭頸 部外科全書 耳(基砚(2)]. 金原出版，東京，1988，105 -132頁.

9) Mark H, Robin H, Michael LW et al: High-frequency electrostimulation hearing after mastoidectory. Otolaryngol Head and Neck Surg 100 : 49-55, 1989.

10) Flottorp G: Effects of noise upon the upper frequency limit of hearing. Acta Otolaryngol $75: 329$ $-331,1973$.

11) Axelsson A: The vascular anatomy of the cochlea in mann. Acta Otolaryngol 244 (Suppl) : 1-134, 1968.

12) Johnsson LG, JE Hawkins: Vascular changes of the human inner ear associated aging. Ann Otol Rhinol Laryngol 81 : 364-376, 1972.

(1989年11月20日受稿１990年 1月29日受理)

別刷請求先 $\overline{\mathbf{T}} 890$ 鹿児島市宇宿町 $1208-1$ 鹿児島人学医学部耳鼻咽喉科学教室 小川和昭 